\title{
Opinions of High School Students and PCG Teachers Participating in the Study about the Forum Theatre Training Process
}

\author{
Fehime Nihal Kuyumcu \\ Hasan Ali Yücel Faculty of Education, Istanbul University, Turkey
}

Copyright $(2018$ by authors, all rights reserved. Authors agree that this article remains permanently open access under the terms of the Creative Commons Attribution License 4.0 International License

\begin{abstract}
This essay is about the evaluation by 12 students and a $\mathrm{PCG}^{1}$ teacher participated in the Forum Theatre training in a state high school in Istanbul. Answers by participating students and the PCG teacher to the open ended question are evaluated through qualitative research techniques. The answers reveal that Forum Theatre has a positive and constructive impact regarding anger management, establishing peace in school premises, developing tolerance towards each other and self-criticism. This study proves that Forum Theatre can be used as a tool for problem solving and help PCG teachers.
\end{abstract}

Keywords High School Students, Youth Problems, Problem-solving, Forum Theatre

\section{Introduction}

Forum theatre is an interactive form of theatre, which is a sub-genre of The Theatre of the Oppressed developed by South American playwright/theoretician Augusto Boal. Unlike Aristotelian theatre which assumes an invisible wall between the stage and the audience, in the Theatre of the Oppressed actors and spectators are in communication with each other continuously. When Aristotelian theatre aims at catharsis only, Brechtian theatre aims [4] a critical consciousness in the audience. However, Boal [2] seeks a kind of theatre where the audience gains critical consciousness and the power to change the world.

"Theatre of the Oppressed" workshops use "Image Theatre" or "Forum Theatre" techniques. All the differences between the actor and the spectator, teacher and learner, narrator and listener, performer and watcher become unimportant. (...) Activity moderator, whom we call Joker, arranges the interaction between the audience and the actors. Joker acts as a facilitator when the audience and the actors discuss their genuine problems and The Joker uses theatrical methods for that objective. The real source of the activity is participants or spectators who bring their own life stories and images to the stage and transform and reform those life experiences for each other. Those on stage, in other words actors, put obstructions to spectators when solving a problem. Since it is not so easy to handle the problems in reality, spectators are somehow forced to think of deeper solutions. It is expected from the actor and the Joker to make the questions visible and as complex as in real life situations. Thus the rehearsal on stage gets very much closer to life.[5]

Forum theatre is a field of practice of the actual life by helping the audience consider their own problems in their own conditions and to find valid solutions that have actual and practical value for them. What makes the Forum Theatre important are as follows; a. There is no solution imposed on the audience, $\mathbf{b}$. The audience is encouraged to discover their limitations and then find out the probable solutions that they can implement. [1]

When bringing solutions to problems encountered in daily life it is most of the time an outsider's suggestions and recommendations without internalizing the problem and the solution lacks an authentic experience or feeling. Thus, personal traits, cultural and traditional differences, the fact that even little details in human nature can have huge impacts are ignored. As humans are social beings and their personal traits are shaped by the society they are both the source and the victim of the pressure imposed on them. Surrounded by several pressure models (written and unwritten ones) people internalize and are exposed to the following pressure models. 
Table 1. Sweet Medicine Teaching

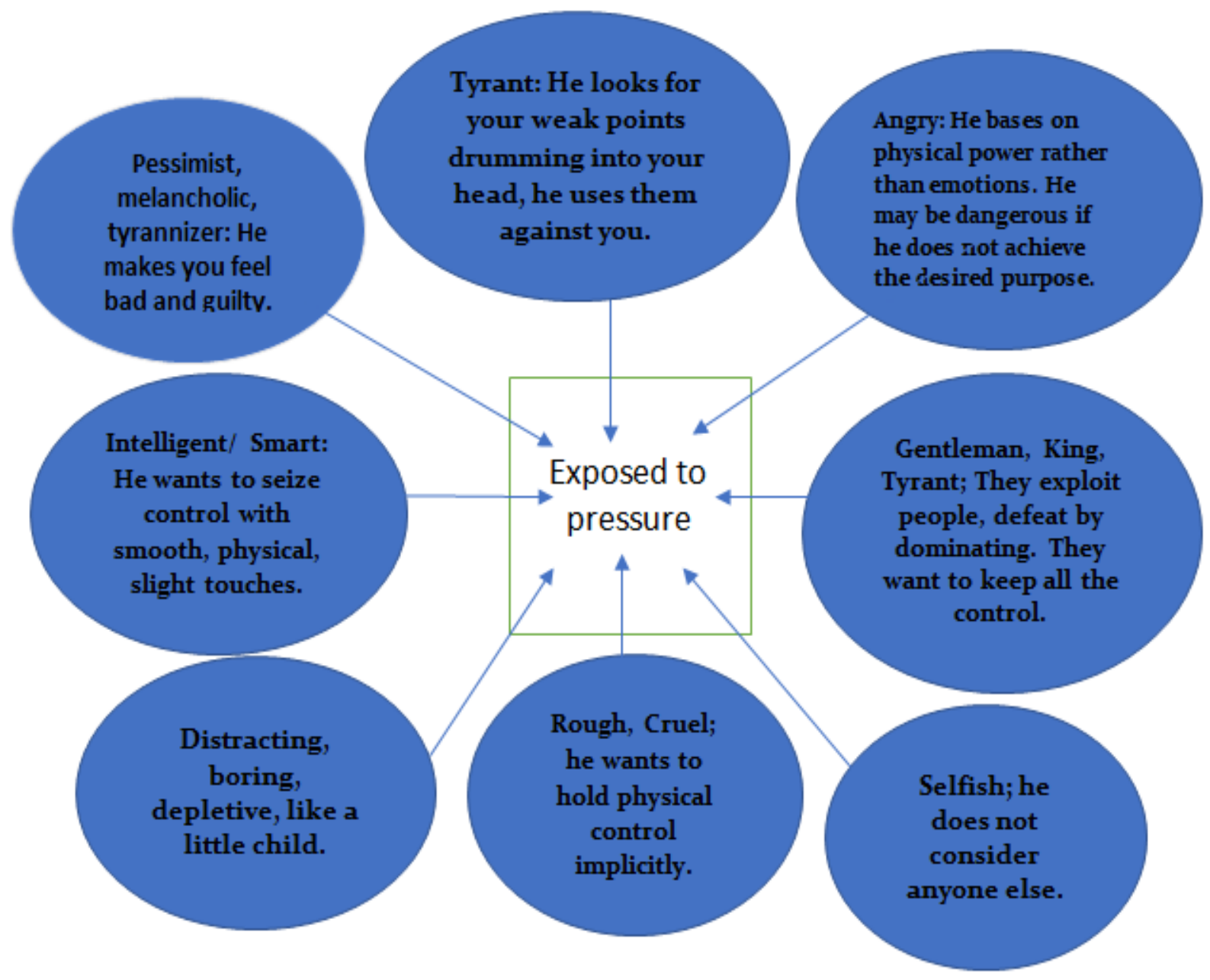

As in the table [7], we actually meet pressure models that we take for granted and internalize. This pressure does not have to come from an authoritarian government or a boss who crushes workers. Bullying in a school environment is also a pressure model.

What makes Forum Theatre eligible against these pressure models lies in the fact that it helps the audience see their own problem; it creates an awareness of that problem, it finds the most valid solution to that problem and helps the audience exhibit the solution. Forum Theatre is located between social relations in real life and theatre's social relations with its aesthetic and social processes. [10] A Participant looks for ways of putting their relations in order in real life and in its fictional world.

This kind of theatre has three principal functions and the first one is pedagogic. The play, designed to search for a solution and to be performed by students, not only encourages the students to acquire awareness regarding their own problems but also informs the adults regarding the problems of the students. Peer guidance comes into play automatically at a period of time when they pay more attention to their peers than adults (their teacher, parents, etc.) The important thing for peer guidance is to look for and find best ways of solution together for themselves instead of an arrogant and didactic attitude of adults. [9].

The Second function is its being therapeutic. [3] Spectators' seeing similar problems on stage have a therapeutic influence on them. Being in a homogeneous group of spectators is important. Trying to solve one's problems in an unreal environment (the stage) facilitates the process and provides a safe space. When spectators are transformed into actors, their awareness of both the real world and sharing the virtual environment bring along a state of metaxis. Thus, they start to think about solution proposals which are applicable.

The Third function is its being social. Since all problems have a social dimension and all outcomes of the solution or chaos processes have an impact on society, searching for solution and finding it together in the course of Forum put the method on test and reveals its validity.

Forum Theatre can be used in several fields, in any institution facing problems and conflicts. It can be used in NGO's, schools, workplaces and hospitals. 
Forum Theatre can be applied from $7^{\text {th }}$ grade on. It is especially an efficient education tool for young people in high school. Students not only make theatre and experience working in a team but also experience thinking together, question themselves, talk and discuss their problems. This is a process of awareness.

\section{Opinions of Students and PCG Teacher about This Study Process and After}

Students and a PCG teacher participated in Forum Theatre workshop process in 2016-2017 academic year in a vocational high school in Istanbul about awareness created by Forum Theatre, expressed their opinion about the subject. Following the workshops, the performance took place in the school auditorium to be watched by other students as well. After the performance participating students were asked one open-ended question; "What do you think about the workshop and staging process regarding the Forum Theatre?" PCG teacher's question was as follows; "What do you think about Forum Theatre activity? What are the advantages and disadvantages for your students?" The answers were given in written form. The students who formed the study group were carefully selected, with the help of PCG teacher. PCG teacher stated that those students had anger management problems, absenteeism, peer pressure and familial traumas and they needed PCG support.

\section{Examples from Received Data}

Below are some examples on Forum Theatre workshop and Forum process from the participants.

Forum Theater's contributions to me;

- I got a new and different social environment.

- My self-esteem has improved.

- I have developed the ability to take responsibility by participating in these studies voluntarily and on time every week because our work is a team work.

- I have developed a sense of observation.

- I started to consider cases and event within the framework of cause and effect.

- When I face with an unexpected event, I can now take my anger under control more easily.

- I have been a calmer person since I joined Forum Theatre studies. Now, I can take my anger under control whereas I couldn't before. I used to make a mess out of an issue by making it bigger but now I can now take care of it by talking it out and changing its tune. And the most important thing is that I have started to like people since I joined Forum Theatre studies. Previously, I would not consider, pay attention to people's thoughts. I overcame the prejudice against people thanks to Forum Theatre.

- Forum Theatre made me feel calmer and think straight. When I fought, I saw and learned to take care of it by talking in any case. I learned that some things would get better when you talk. When I see people fighting I now find it so bad and disgusting. It arises a sense of remorse. We made friends with new people and Forum Theatre was really useful to us.

\section{Grouping the Data}

A total of 12 students and 1 PCG teacher's opinions and answers in accordance with asked question were grouped.

These groups are:

1- Opinions about increased awareness related to themselves or their environment.

2- Opinions of those who think that they obtained clues about the formation of the life practice.

3- Opinions of the ones who think that it had a therapeutic effect.

4- Opinions of the ones who think that they reached common a ground for trouble shooting.

5- Opinions of the ones who think that it contributed to their personal development. (A better self-expression)

6- Expressions of the ones who appreciate the group work.

\section{Opinions of Students in Terms of Achievements Related to the Forum Theatre and Workshop Process}

Opinions of the ones who think that awareness related to themselves and their environment:

We have noticed that there could be a different point of view related to everyday issues we witness daily and we have gained awareness towards our prejudices. Forum Theatre is not just an ordinary theatre, but also a space for awareness. --Forum Theatre is like an awareness centre. -The spectator finds something of him on stage, sees himself. -- I have started to love people since I joined the Forum Theatre Studies. - Previously, I wouldn't care about people's thoughts. I overcame my prejudice against people thanks to Forum Theatre. - Forum Theatre made me calmer and think straight. When I fought, I saw and learned to take care of it by talking in any case. I learned that something could change by talking. -- It seemed like a mirror to me rather than learning something. I found the opportunity to watch it from outside. -- I saw my good and bad sides. - Theatre provides me an ability to develop empathy. -- When I see people fighting I now find it so bad and disgusting. It arouses a sense of remorse. We made friends with new people and Forum Theatre was really 
useful to us.

PCG Teacher's View: Forum theatre helps many of our students handle their problems and find realistic so when I see people fighting I now find it so bad and disgusting. It arouses a sense of remorse. We made friends with new people and Forum Theatre was really useful to us.

\section{Opinions of Those Who Think that They Obtained Clues about the Formation of the Life Practice}

- The solution or chaos leaves a lasting impression on life - During the Forum, we learn how to look at situations in a broader sense from different directions and we try every solution. Our horizon opens up when searching for solutions in the forum. - We learn to think of all the options and run the risk of their results in the Forum. During the forum, we try to break it and build a new one by going to the future for a moment and seeing where things could reach up. On stage, we tried to overcome the problems with ideas/suggestions. - That's how I started to get to know people.

\section{Opinions of the Ones Who Think that It Had a Therapeutic Effect}

Forum Theatre is something like therapy, -- I feel very comfortable, -- I feel relieved after a tiring week. Throughout the study period we feel very well. This process is very instructive and helps me develop empathy, so I can communicate properly. Being in such a workshop makes me feel more optimistic.-- I've been a calmer person since I joined the Forum Theatre studies.-Now I can take my anger under control whereas I couldn't do it previously.

\section{Opinion of PCG Teacher}

The workshop showed us that students, who had a lot of absenteeism, attended the Forum Theatre studies regularly. They also developed self-discipline. Another student who used to accuse other people for whatever happened and suffered from nervous breakdowns has developed empathy and calmed down during the process.

\section{Opinions of Those Who Think They Reached a Common Ground Regarding Trouble Shooting}

Common values are being built unintentionally. Thus, we gain new perspectives and approaches in solving a problem. People who are experiencing the same problems are looking at their own problems and they are also performing for people suffering from the same problems. We are looking for solutions and trying to find them. This is really important.

\section{Opinions of Those Who Think It Contributed to their Personal Development. (A better self-expression)}

--It is like a kind of personal development activity.
Through Forum Theatre we learn to look at situations in a wider sense from different directions. The plays we performed after improvisations helped us see things differently. -- This process is very instructive and helped us develop empathy. In this sense, I also learned to evaluate my own approaches against problems. Everyone can go out on the stage and express themselves. My selfconfidence has improved. I have developed the ability to take responsibility by participating in these studies voluntarily and on time every week because our work is a team work. I have developed a sense of observation. I started to consider cases and event within the framework of cause and effect. When I face with an unexpected event, I can now take my anger under control more easily. In the face of unexpected events, I can now control my anger better. When I made a situation out of nothing and more insoluble, nowadays, I can take care of it by changing my tune and talking. -- I learned a little more about how to behave the other. - I learned to value and being valued. I got a new and different social environment.

-My self-esteem has improved.

\section{PCG Teacher's Opinion}

The study revealed that students who were reluctant to take part in the activities and show their emotions due to peer pressure have developed better communication skills and opened up. Another isolated student who cannot acquire social skills because of his traumatic past shows a desire to participate in activities in the school voluntarily and takes responsibility after the process of Forum Theatre.

\section{Expressions of the Ones Who Appreciate the Group Work}

Synergy is created; you are positively influenced by the group. I got a new and different environment. I learned to work in groups. I learned to use time efficiently since it was a team work. -- I met new people and made new friends. - We had fun.

\section{PCG Teacher's Opinion}

It is undeniable that Forum Theatre has positive effects in terms of bringing awareness to both the participants and the spectators. It should be kept in mind that Forum Theatre is an efficient tool that PCG services can use.

\section{Discussion}

Today, FT is used in many parts of the world as an educational tool. For example, since 1997 in the battle fields of Palestine [8], it has been used mainly in rural 
areas, with women and marginalized groups, focusing on problem-solving in schools. In Brazil, in prisons in Sao Paulo, in Canada Vancouver with homeless people, many studies have been carried out and it is an ongoing process. It is also used in Canada as an improvement tool especially in schools against racism. Linds [6], Wrentschur and Moser [10] A European Union project "Stop: We are talking now! A Creative and Extraordinary Approach for Strengthening Disadvantaged Youth" was carried out in 16 different premises and those FT studies have reached about 1000 people and eventually 513 people were given questionnaire forms and the study was supported by observation and interview forms. When the obtained data were evaluated, positive results were obtained. It was seen that The FT is an important force to detect the problems young people face with and it is also an efficient tool to make the decision-making bodies hear about these problems.

The outcomes we have obtained after the FT workshops have overlapped with the results of the studies done previously.

\section{Conclusions}

This study is a report of evaluation on the Forum Theatre workshop carried out in a vocational high school İstanbul in 2016-2017 academic year.

The overall theme of the workshop underlines the subjects such as awareness, personal development, teenager problems, and voluntary work. Students themselves have expressed their development on the above mentioned issues as well as their teacher's opinion, which supported the one of the students.

Improvisations during the workshops helped students express the problems they had with their parents, friends through games, plays and fiction. The fact that they could empathize with those who they had clashes is a sign that they developed awareness towards those issues. The answer they gave is a clear sign of their awareness.

When the answers are evaluated through personal development perspective, the students have been observed to have expressed their positive impressions which overlap with the workshop process. The students who had anger management issues and kept an isolated attitude started to communicate properly and sought for dialogue for the solution of the problems after the workshop process, which is another sign of the positive impact of the Forum Theatre workshop.

Participating students expressed the fact that those problems are typical of teenagers' and they repeated the typical sentence "nobody understands me" during the workshops. The problems that they mentioned have reached the adults, PCG teacher, parents, school management.

Despite being reluctant at first, from the third week on, they willingly attended the workshops, took responsibility and fulfilled their responsibilities eagerly. Their eagerness and willingness were also visibly reflected in their studies which was also observed and proved by their teachers and the school management.

Forum Theatre is a theatre model which helps the participants look into, observe and find solutions to their problems rather than an interventionist, preaching method. The spectator comes on the stage and intervenes the process, brings recommendations towards the problem and those recommendations are disputed by their peers. This process makes the participants think over the problems from several viewpoints.

Another important and valuable aspect of Forum Theatre is that all this process is carried out by the participants and their peers. The lack of adult intervention eliminates authoritarian, patronising adult viewpoint that participants are used to. Thus, participants come across with an alternative way of solving problems which could also help those becoming responsible individuals. Forum Theatre is just a tool without dictating and pointing at a certain direction.

This workshop, initiated to find solutions to the problems encountered in the school premises, proves that peaceful communication could reach to a certain level and participants became more tolerant to others around them. This outcome has been approved by both students and the teacher. Self-criticism and awareness they claimed to have gained have also been approved by the teacher as a positive development, which altogether proves the constructive power of Forum Theatre. Forum Theatre studies could easily be recommended as a useful tool after $8^{\text {th }}$ grade in high schools in order to help PCG teachers solve problems, establish peace.

\section{REFERENCES}

[1] Boal, A, 1996, "EzilenlerinTiyatrosu" (Theatre of the Oppressed) Etki Publishing, İzmir

[2] Boal,A, 2003 Oyuncular ve Oyuncu Olmayanlar İçin Oyunlar (Games for Actors and Non-Actors) Bosporus University Publications, İstanbul

[3] Boal, A. 2008 Arzu Gökkuşağı,( The Rainbow of Desire: The Boal Method of Theatre and Therapy) Bosporus University Publications, İstanbul

[4] Brecht, B. 1993, Tiyatro İçin Küçük Organon, (A Short Organum for the Theatre) Mitos Boyut Publishing, İstanbul

[5] Güllü F. 2011 “Gestus, ÖzgürleşenSeyirci” (Gestus, Liberated Audience)

http://www.mimesis-dergi.org/2011/11/gestus-ozgurlesenseyirci/ (Quotation date:17.04.2017).

[6] Linds W., 1998 Theatre of the Oppressed: Developing A 
Pedagogy Of Solidarity? Volume 19 Number 2 / Fall https://journals.lib.unb.ca/index.php/tric/article/view/7110/ 8169

[7] Malbogat, S. Iogna, L. (2003) Workshop Leaflet, 2003,

[8] Moore, E. 2009 Forum Theatre Participedia http://participedia.net/en/methods/forum-theatre

[9] Nazlı, S. Uysal, D. 2010, Akran Yardımcılığı
Müdahalesinin Etkililiği: Balıkesir Karesi İlköğretim Okulu Örneği, Balıkesir Üniversitesi Sosyal Bilimler Enstitüsü Dergisi Issn1301-5265 Cilt13 Say1 23 Haziran 2010 p.13

[10] Wrentschur, M., Moser M. 2014 "Stop: Now we are speaking!'A creative and dissident approach of empowering disadvantaged young people" International Social Work 2014, Vol. 57(4) $398-410$ 